\title{
Early Cambrian "soft-shelled" brachiopods as possible stem-group phoronids
}

Uwe Balthasar and Nicholas J. Butterfield

Acta Palaeontologica Polonica 54 (2), 2009: 307-314 doi:http://dx.doi.org/10.4202/app.2008.0042

Brachiopods and phoronids are widely recognised as closely related lophophorate phyla, but the lack of morphological intermediates linking the bivalved bodyplan of brachiopods with tubular phoronids has frustrated precise phylogenetic placement. Here we describe Lingulosacculus nuda gen. et sp. nov., a new "soft-shelled" brachiopod from the Early Cambrian Mural Formation of western Alberta which provides a plausible candidate for a phoronid stem-group within (paraphyletic) Brachiopoda. In addition to its non-biomineralised shell, L. nuda had a ventral valve with an exceptionally long, pocket-like extension (pseudointerarea) that would have allowed the transformation of criss-crossing brachiopod-type musculature to the longitudinal arrangement typical of phoronids. "Soft-shelled" linguliform brachiopods have previously been reported from both the Chengjiang and Burgess Shale Lagerstätten which, together with L. nuda, probably represent two independent losses of shell mineralisation in brachiopods.

Key words: Lophophorata, Lophotrochozoa, Brachiopoda, Phoronida, exceptional preservation, problematica.

Uwe Balthasar [uwe.balthasar@geo.uu.se], Department of Earth Sciences, Uppsala University, Villavägen 16, 75236 Uppsala, Sweden; Nicholas J.

Butterfield [njb1005@esc.cam.ac.uk], Department of Earth Sciences, Cambridge University, Downing Street, CB2 3EQ Cambridge, United Kingdom.

This is an open-access article distributed under the terms of the Creative Commons Attribution License (for details please see creativecommons.org), which permits unrestricted use, distribution, and reproduction in any medium, provided the original author and source are credited. 
Forif Full text $(382.0 \mathrm{kB})$ 